Article

\title{
Compaction Process as a Concept of Press-Cake Production from Organic Waste
}

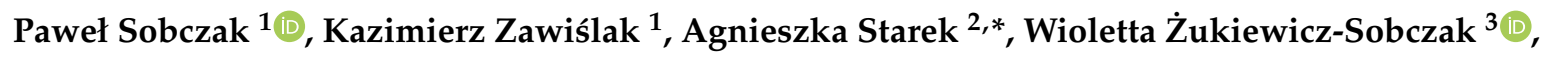 \\ Agnieszka Sagan ${ }^{2}$, Beata Zdybel ${ }^{2}$ and Dariusz Andrejko ${ }^{2}$ \\ 1 Department of Food Engineering and Machines, University of Life Sciences in Lublin, Akademicka 13, \\ 20-612 Lublin, Poland; pawel.sobczak@up.lublin.pl (P.S.); kazimierz.zawislak@up.lublin.pl (K.Z.) \\ 2 Department of Biological Bases of Food and Feed Technologies, University of Life Sciences in Lublin, \\ Akademicka 13, 20-612 Lublin, Poland; agnieszka.sagan@up.lublin.pl (A.S.); \\ beata.zdybel@up.lublin.pl (B.Z.); dariusz.andrejko@up.lublin.pl (D.A.) \\ 3 Pope John Paul II State School of Higher Education in Biala Podlaska, Sidorska 95/97, 21-500 Biala Podlaska, \\ Poland; wiola.zukiewiczsobczak@gmail.com \\ * Correspondence: agnieszka.starek@up.lublin.pl; Tel.: +48-81-531-9647
}

Received: 31 January 2020; Accepted: 18 February 2020; Published: 19 February 2020

\begin{abstract}
As a result of agri-food production large amounts of organic waste are created in the form of press cakes. Until now, they were mainly used as animal fodder and also utilized for biofuels production. No other way usage has been found yet. A large quantity of these by-products is usually discarded in open areas, which leads to potentially serious environmental problems. The rich chemical composition of these waste products makes it possible to use them for producing other food products valuable for consumers. Based on the test results obtained, it can be stated that moisture content of press cakes is varied and depends on the input material. However, appropriately composed mixtures of various waste products and a properly conducted compaction process allows for obtaining a new product with functional properties. In addition, application of honey powder and starch tablet coating creates a product of resistant to compression and cutting. Results seem to have commercial importance, as they demonstrate that properly processed by-products can be used in food preparations as dietary supplements.
\end{abstract}

Keywords: press cakes; compaction; disposal; sustainable development; modern products

\section{Introduction}

In the food industry, during processing of raw materials, waste products are generated. Their substantial amounts accumulated in a short time causes serious problems for processing plants, primarily due to the instability of these by-products, including the microbiological one. Therefore, they should be used as an intermediate for further processing. In general, around the world waste management is carried out to convert into useful components as much waste products as possible without endangering the natural environment [1-5].

A particularly large amount of waste is produced during cold-press edible oil extraction. A common method of using press cakes from rapeseed, flaxseed, and sunflower extraction, is their utilisation for animal nutrition as a high protein vegetable fodder or as a component for enriching the protein content in the production of maize silage, which is intended for high-yielding cows. The use of press cakes reduces the cost of animal nutrition products [6-8]. They can also be successfully used as organic fertilizer rich in minerals $(\mathrm{Ca}, \mathrm{Mg}, \mathrm{P}, \mathrm{Fe}$, and $\mathrm{Mn}$ ) and organic compounds, as well as for energy purposes [9-12] after a compaction process that turns them into pellets [13,14]. Press cakes can be used for manufacturing formulated products such as functional foods. Compaction could be a 
particularly important method for processing press cakes in the areas where there is a surplus of them, there is no possibility for their fast processing into fodder, and transport over long distances is not economically viable [15].

Production of coconut oil also entails generation of waste. The research done by Ramachandran et al. $[16,17]$ confirms that these press cakes are characterised not only by a clearly sweet taste, but also high content of amino acids (mainly arginine). They are also used as a potential raw material in bioprocesses, as they are an excellent substrate for growing microorganisms (substrates for the production of phytase based on the use of Rhizopus spp. strain).

Avocado oil, pressed from fruit pulp, is nowadays used as a dietary supplement reinforcing body resistance and improving skin appearance. Moreover, it is used for production of cosmetic goods [18]. At the same time avocado pit, until lately considered inedible, has recently been the subject of scientific interest. As reported by Soong et al. [19] and Wang et al. [20] this hard part of the fruit contains many more polyphenols, exhibiting intense antioxidant activity, than the pulp itself. According to the ORAC scale for determining the free radical absorbance capacity of antioxidants, the pit of the fruit has high antioxidant potential, equal to $428.8 \mu \mathrm{molTE} / \mathrm{g}$ for the Hass variety. For comparison, the same quantity of pulp only has a potential of $11.6 \mu \mathrm{molTE} / \mathrm{g}$. Avocado extracts, thanks to their polyphenol content, expressed as gallic acid equivalents, are already used in cosmetic care [21], as well as a means to delay the oxidation of sunflower oil [22]. Moreover, many studies confirm [23-26] that avocado pit has cytotoxic properties, inter alia, against breast, lung, colon, and prostate cancer cells.

Individual types of waste are increasingly used in various industries $[27,28]$. In the scientific literature, however, there are no reports on their comprehensive use to obtain a valuable products intended for human consumption. In addition, there are difficulties in the proper preparation of this organic waste (ensuring adequate moisture content, disintegration and chemical composition) and their appropriate concentration [14,15]. Therefore, the aim of the study is to determine the potential use of organic waste and combine it in such a way as to obtain a new, stable product with pro-health properties.

\section{Materials and Methods}

\subsection{Research Material}

Materials used for the study consisted of flax, sunflower, pumpkin, and coconut press cakes, and powder avocado pit created during cold-press oil production. In order to obtain a uniform product all raw materials were mixed and subjected to compaction in a chamber equipped with a piston (Figure 1), where they were formed into a tablet. Before blending the compound press cakes were ground to a uniform size. The percentage share of particular components constituting the blend is shown in Table 1. The press cakes were sampled immediately after cold-press oil extraction using a screw press (model DUO Farmet, Česká Skalice, Czech Republic), while the avocado pit was cut into smaller pieces, dried in an SLN 15 STD type laboratory drying oven, manufactured by the POL-EKO Company (Wodzislaw Ślaski, Poland), at a temperature of $40^{\circ} \mathrm{C}$ for 1.5 hours, and then ground in a mill so that powder was obtained.

Table 1. Percentage share of individual raw materials in the compound.

\begin{tabular}{ccc}
\hline Type of Raw Material & Compound 1 & Compound 2 \\
\hline Flax press cake & 30 & 29 \\
Sunflower press cake & 20 & 20 \\
Pumpkin press cake & 30 & 29 \\
Avocado pit & 5 & 5 \\
Coconut press cake & 15 & 15 \\
Honey powder & 0 & 2 \\
\hline
\end{tabular}


Shares of particular components were selected having in mind the possibility of obtaining value products in form of a stable tablet. To Compound no. 2 a $2 \%$ of dried honey was added. The purpose of this admixture was to obtain a stable tablet form by combining particles of honey with the remaining raw materials.

Then the tablets were divided into two groups and one of them was coated with a thin layer of starch solution. For this purpose a $40 \%$ solution of potato starch was prepared which was heated to the temperature of $40^{\circ} \mathrm{C}$ in order to obtain lower viscosity. Surface of the tablets was coated using a spray nozzle. Afterwards, the tablets were left to dry at room conditions for 24 hours.

\subsection{Measurement of Chemical and Physical Properties of Post-Production Waste}

Fat content was determined in the obtained press cakes as well as in the fragmented and dried avocado pit using an automatic Soxhlet apparatus (Tecator Soxtec System HT 1043 extraction unit, Gemini, Apeldoorn, Sweden). Total protein content measurements were carried out according to the Kjeldahl method using a Kjeltec 8400 automatic distiller (Foss, Foss Anatytical AB, Höganäs, Sweden). The total protein content was calculated using a 6.25 conversion factor. Determination of the ash content in the press cakes was done in a muffle furnace according to PN-EN ISO 18122:2016-01 [29] standard. Analysis of mineral composition included the determination of the amount of: calcium, copper, iron, potassium, magnesium, and zinc by using ICP OES spectrometer (SpectroBlue, SPECTRO Analytical Instruments $\mathrm{GmbH}$, Kleve, Germany). Analytical curves were prepared by dilutions of VHG SM68-1-500 Element Multi Standard 1 in 5\% $\mathrm{HNO}_{3}$. Moisture content of the raw materials was determined using a laboratory drying oven with forced air circulation. Samples of raw materials were placed in the oven chamber and then dried at the temperature of $105^{\circ} \mathrm{C}$ until constant weight was achieved, in accordance with PN-EN-ISO 18134-3:2015-11 [30] standard.

\subsection{Methodology of the Tablet Forming Process}

The tablet forming process was carried out with a ZO20/TN2S machine (Zwick.Roell AG, BT1-FR0.5TN.D14, Ulm, Germany) using the designed attachment shown in Figure 1.

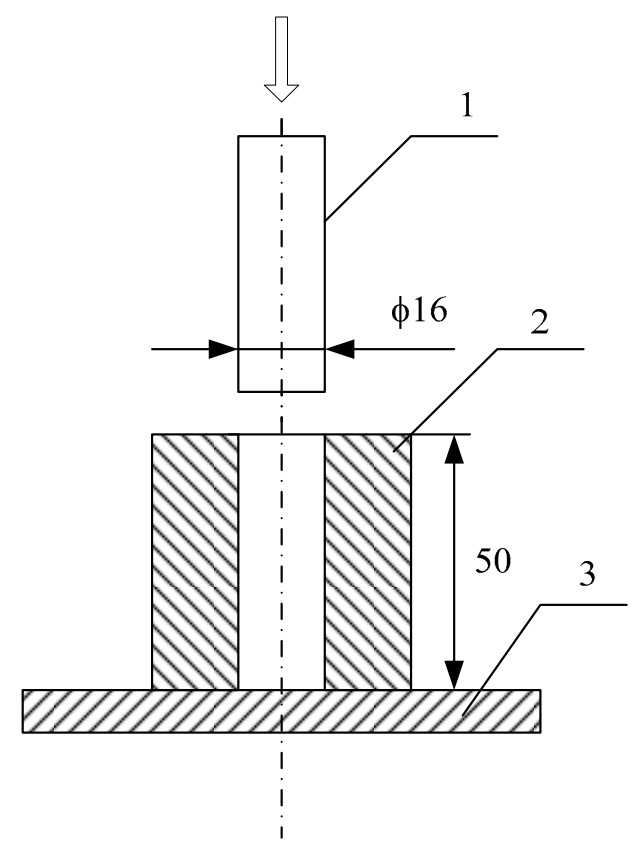

Figure 1. Workstation for forming tablets out of the compound: 1-piston, 2-feed hopper, 3-base.

The pressing force exerted by the piston was constant, equal to $20 \mathrm{kN}$. The head pressing the piston, allowed for the formation of a single agglomerate with the weight of $2 \mathrm{~g}$. Compaction work 
and specific density of the obtained tablets was designated by means of testXpert software, which is used to operate the Zwick devices.

\subsection{Methodology for Assessing Strength of the Tablets}

The tablets (Figure 2) were analysed by examining the cutting force and hardness. The stress tests were carried out using a Micro Stable Pro TA.XT Plus system (Stable Micro Systems Ltd, Surrey, United Kingdom).

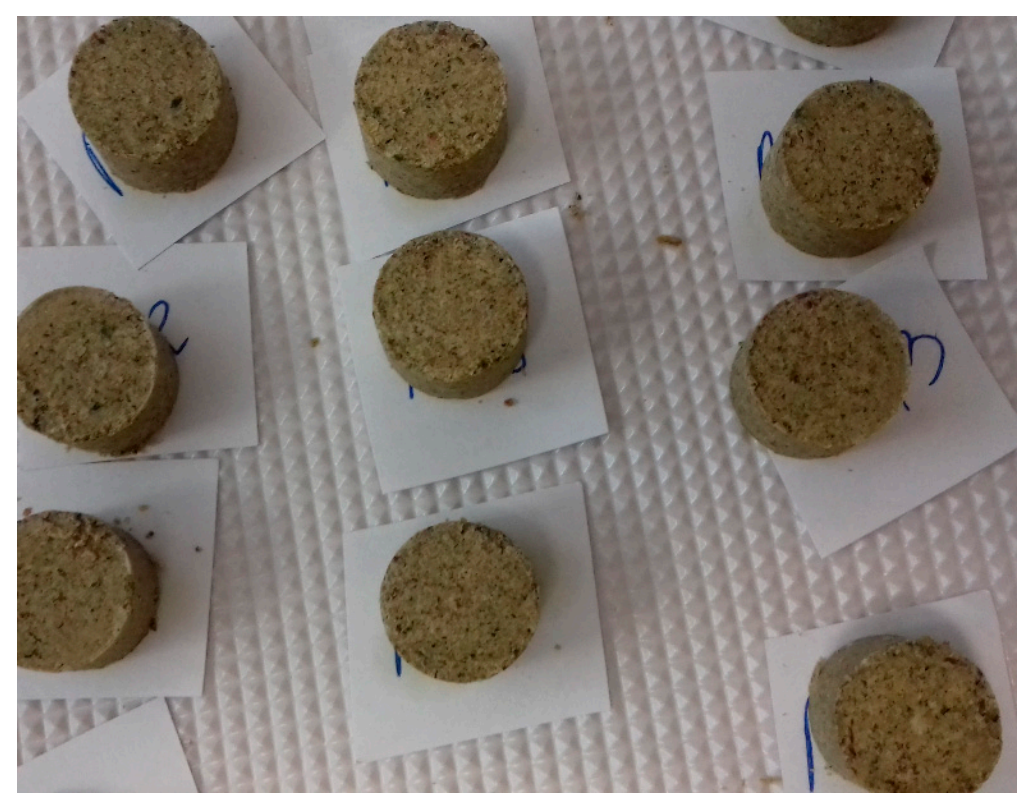

Figure 2. Tablets obtained out of the compound.

The method of placing a single tablet for the cutting force test and hardness test is depicted in Figure 3. In the cutting test a knife with the cutting edge angle of $45^{\circ}$ was used. The test was run until the tablet was cut into half. The hardness test was made using a flat head and recording the compression force until reaching half the diameter of the tablet. The tests were performed in 10 repetitions.

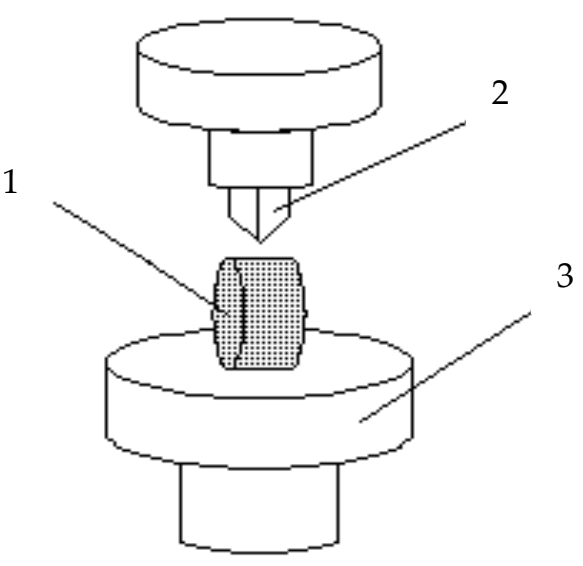

Figure 3. Method of placing the sample for the cutting force test: 1-sample, 2-cutting knife, 3-measuring table. 


\subsection{Statistical Analysis}

Results were statistically analysed with Statistica 10.0 software (Statistica 10, StatSoft Inc., Tulsa, OK., U.S.A.), using one-way analysis of variance. The significance of differences between the mean values was tested using Tukey's procedure.

\section{Results and Discussion}

\subsection{Characterization of Chemical Properties of Post-Production Waste}

The results of carried out experiments are shown in Tables 2 and 3.

Table 2. Chemical composition of the press cakes and obtained compounds.

\begin{tabular}{cccccccc}
\hline & \multicolumn{3}{c}{ By-products } & \multicolumn{2}{c}{ Compound } \\
\hline Discriminant & $\begin{array}{c}\text { Flax Press } \\
\text { Cake }\end{array}$ & $\begin{array}{c}\text { Sunflower } \\
\text { Press Cake }\end{array}$ & $\begin{array}{c}\text { Pumpkin } \\
\text { Press Cake }\end{array}$ & $\begin{array}{c}\text { Coconut } \\
\text { Press Cake }\end{array}$ & $\begin{array}{c}\text { Avocado } \\
\text { Pit }\end{array}$ & $\mathbf{1}$ & $\mathbf{2}$ \\
\hline Protein [\%] & $32.47 \pm 0.11$ & $37.65 \pm 0.36$ & $53.98 \pm 0.07$ & $17.40 \pm 0.41$ & $4.78 \pm 0.06$ & $36.2 \pm 0.26$ & $36.1 \pm 0.23$ \\
Fat [\%] & $11.52 \pm 0.07$ & $31.42 \pm 0.25$ & $14.23 \pm 0.05$ & $15.02 \pm 0.04$ & $1.30 \pm 0.21$ & $18.1 \pm 0.04$ & $17.1 \pm 0.06$ \\
Ash [\%] & $5.56 \pm 0.02$ & $4.69 \pm 0.01$ & $8.09 \pm 0.01$ & $4.13 \pm 0.01$ & $2.30 \pm 0.01$ & $5.75 \pm 0.01$ & $5.70 \pm 0.01$ \\
\hline
\end{tabular}

Means of three determinations \pm SD (standard deviation).

Table 3. Content of selected elements in the press cake.

\begin{tabular}{ccccccc}
\hline & \multicolumn{7}{c}{ Content of Selected Elements [ppm] } \\
\hline By-Products & $\mathbf{C a}$ & $\mathbf{C u}$ & $\mathbf{F e}$ & $\mathbf{K}$ & $\mathbf{M g}$ & $\mathbf{Z n}$ \\
\hline Flax press cake & 3489.355 & 11.808 & 135.916 & 8067.798 & 4035.281 & 69.089 \\
Sunflower press cake & 1421.465 & 23.737 & 66.131 & $<0.005$ & 3708.333 & 111.364 \\
Pumpkin press cake & 602.551 & 6.378 & 134.694 & $<0.005$ & 6707.143 & 155.102 \\
Coconut press cake & 394.628 & 20.661 & 75.000 & 10017.355 & 2021.694 & 32.645 \\
Avocado pit & 913.545 & 7.977 & 31.909 & 7143.500 & 759.023 & 8.568 \\
\hline
\end{tabular}

By-products resulting from processing of pumpkin seeds had the highest protein content of $53.98 \%$. In the flax and sunflower press cakes the value of this parameter ranged between 32.39 and $37.91 \%$, while in the case of coconut press cakes its quantity was about half the amount. The avocado pit was characterised by the lowest protein content, equal to $4.78 \%$.

Sunflower press cakes had the highest fat content of $31.415 \%$. The coconut, pumpkin, and flax press cakes were characterised by a significantly lower fat content, i.e. between 15.02 and $11.52 \%$. Ground avocado pit contained a negligible amount of fat equal to $1.30 \%$.

The ash content in the analysed samples varied between $2.30 \%$ (for the avocado pit) and $8.09 \%$ (for the pumpkin seed press cakes).

As it can be seen in Table 3, the calcium content varied very significantly. Flax press cake contained the highest amount of this element, i.e. $3489 \mathrm{ppm}$. In the by-products of coconut oil extraction process, calcium content was about $74 \%$ lower. Copper content in the analysed production by-products was less varied and fell within the range from $6.378 \mathrm{ppm}$ (for the pumpkin press cake) to $23.737 \mathrm{ppm}$ (for the sunflower press cake). Iron content in the waste originating from flax and pumpkin processing was at a similar levels. The analysis showed that avocado pit was characterised by the lowest amount of this element. Potassium content was also determined in the tested by-products. Coconut press cake had the highest amount of this element, equal to $10017.355 \mathrm{ppm}$. Concentration of potassium in the waste resulting from flax seed oil extraction and in the avocado pit was lower respectively by approx. $20 \%$ and $29 \%$. In the remaining by-products subject to the study amount of potassium was below limit of quantification. Magnesium content in the analysed samples varied within the range between 759.023 and $6707.143 \mathrm{ppm}$. The lowest content of this element was measured for the avocado pit. Pumpkin press cake was characterized by a several times higher magnesium content. For the entire studied 
material the highest zinc content was measured for the pumpkin press cake and sunflower press cake. In turn, the lowest amount of this element was recorded in the case of avocado pit.

The chemical composition of the press cakes can be highly variable, depending on the quality of seeds, method of oil extraction, storage parameters, and so on. As confirmed by the studies done by other authors these oil pressing by-products are characterized by high nutritional value. For example, the by-product obtained in the course of oil extraction from dried pumpkin seeds has a high amount of valuable protein and hydrolysates produced from it have antioxidant and functional properties [31]. Research conducted by Salgado et al. [32] shows that sunflower press cakes are also a source of protein with high solubility in water, good physicochemical properties, and high antioxidant activity. The data presented by Ramachandran et al. [17] demonstrate that coconut press cake contains a high level of residual oil consisting of saturated short-chain fatty acids. Moreover, it is characterised by a high content of protein and crude fibre. Literature on chemical composition of sesame press cake [33,34], rapeseed press cake [35], Camelina sativa, and flax press cake [36] also provides a lot of information about their high nutritional value, and confirms that in future by-products will be an important resource for use as a food ingredient for direct human consumption.

\subsection{Analysis of the Compaction Process}

Before the compaction process moisture content of individual components as well as that of the compound was measured (Figure 4).

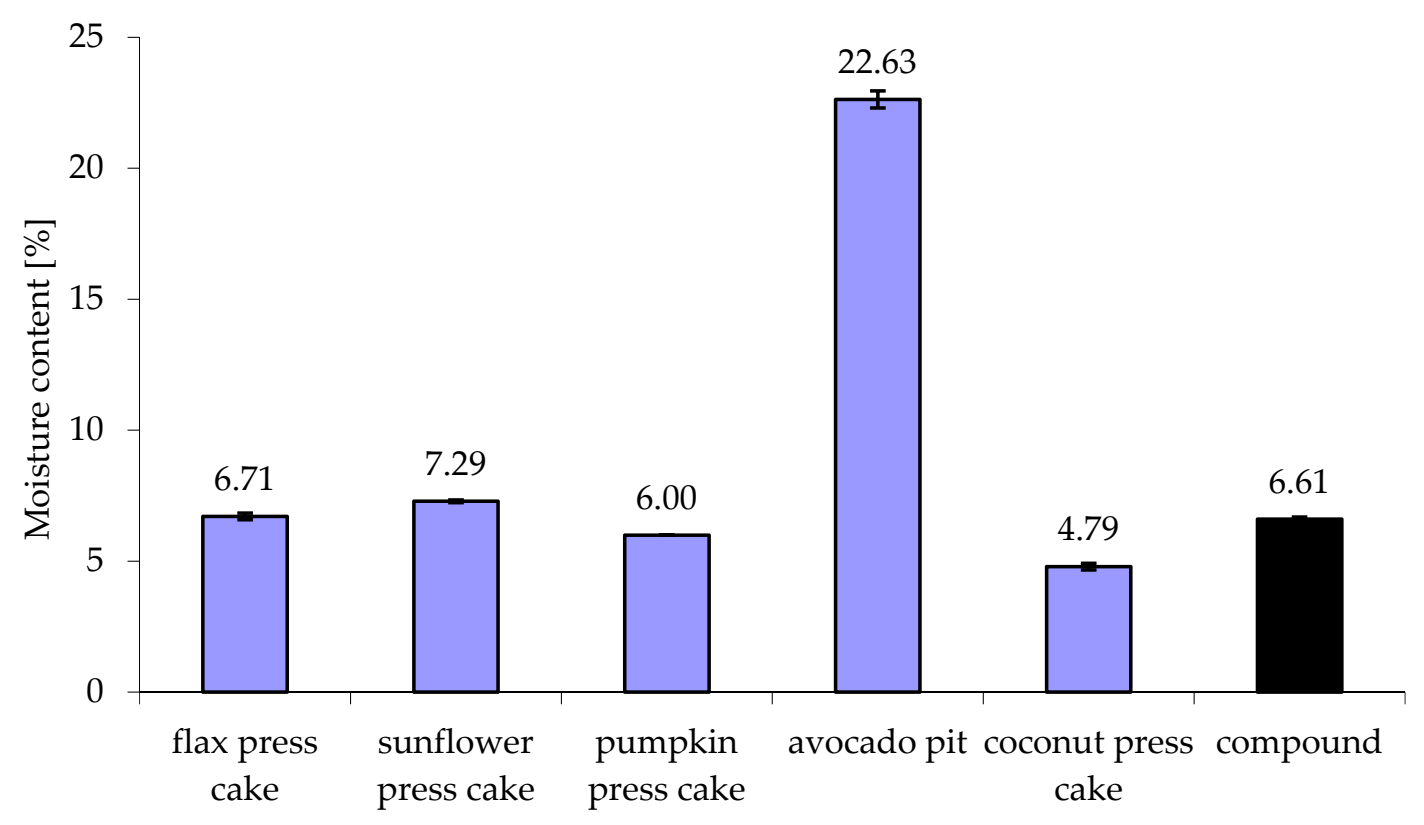

Figure 4. Moisture content of the individual press cakes and the compound.

Avocado pit press cake had the highest moisture content (22.63\%). For the remaining raw materials moisture content varied within the range between $4.79 \%$ (for the coconut press cake) and $7.29 \%$ (for the sunflower press cake). The obtained compound had the moister content of $6.61 \%$.

Moisture content of press cakes is varied and depends on the input material. As reported by research moisture content for oil press cakes ranges from 5 to $9 \%$ [13]. Wojdalski et al. [15] conducted research on the compaction process of apple pomace resulting from juice production, for which, at the temperature of $20^{\circ} \mathrm{C}$ and relative humidity of the air equal to $31.7 \%$, the total compaction energy in the case of unfragmented apple pomace ranged from 66.60 to $150.00 \mathrm{~J} / \mathrm{g}$, while for pellets made from fragmented pomace this parameter was between $34.79 \mathrm{~J} / \mathrm{g}$ and $149.95 \mathrm{~J} / \mathrm{g}$. Specific density of the obtained tablets was respectively within the range of $1114.0-1166.3$ and $1114.0-1168.1 \mathrm{~g} / \mathrm{dm}^{3}$. In the case of examined here compounds a significantly smaller compaction work, i.e. of approx. $9.7 \mathrm{~J} / \mathrm{g}$, was 
necessary to obtain tablets. This is due to high fat content, which for compound 1 was equal to $18.1 \%$, while for compound 2 to $17.1 \%$ (Figure 5).

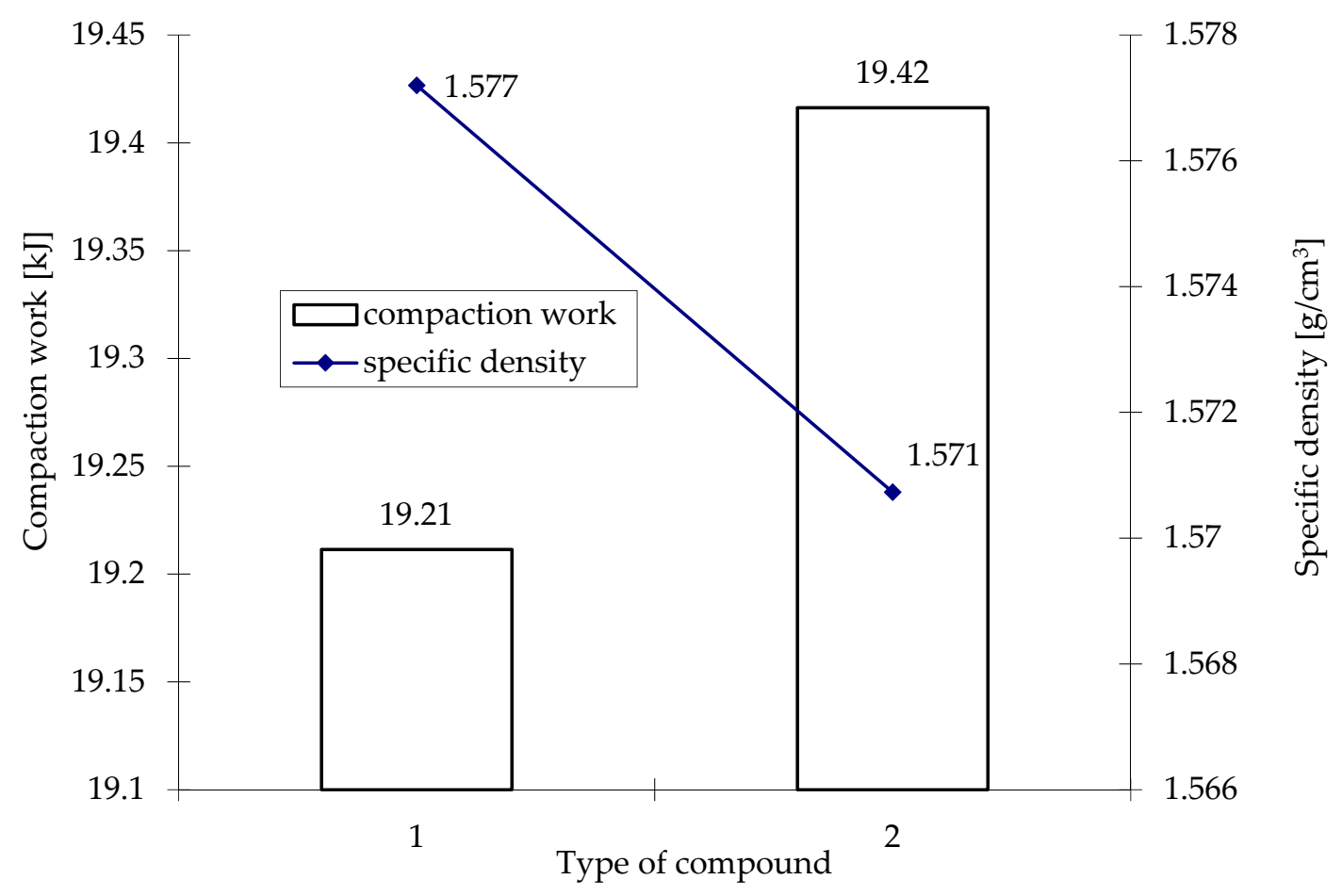

Figure 5. Compaction work and specific density obtained after forming tablets out of the compound.

\subsection{Evaluation of the Obtained Tablets}

In accordance with the accepted methodology the obtained tablets were subject to stress tests in order to determine the impact of adding honey and coating technology. Figures 6 and 7 and Table 4 show results of respectively the cutting test and hardness test.

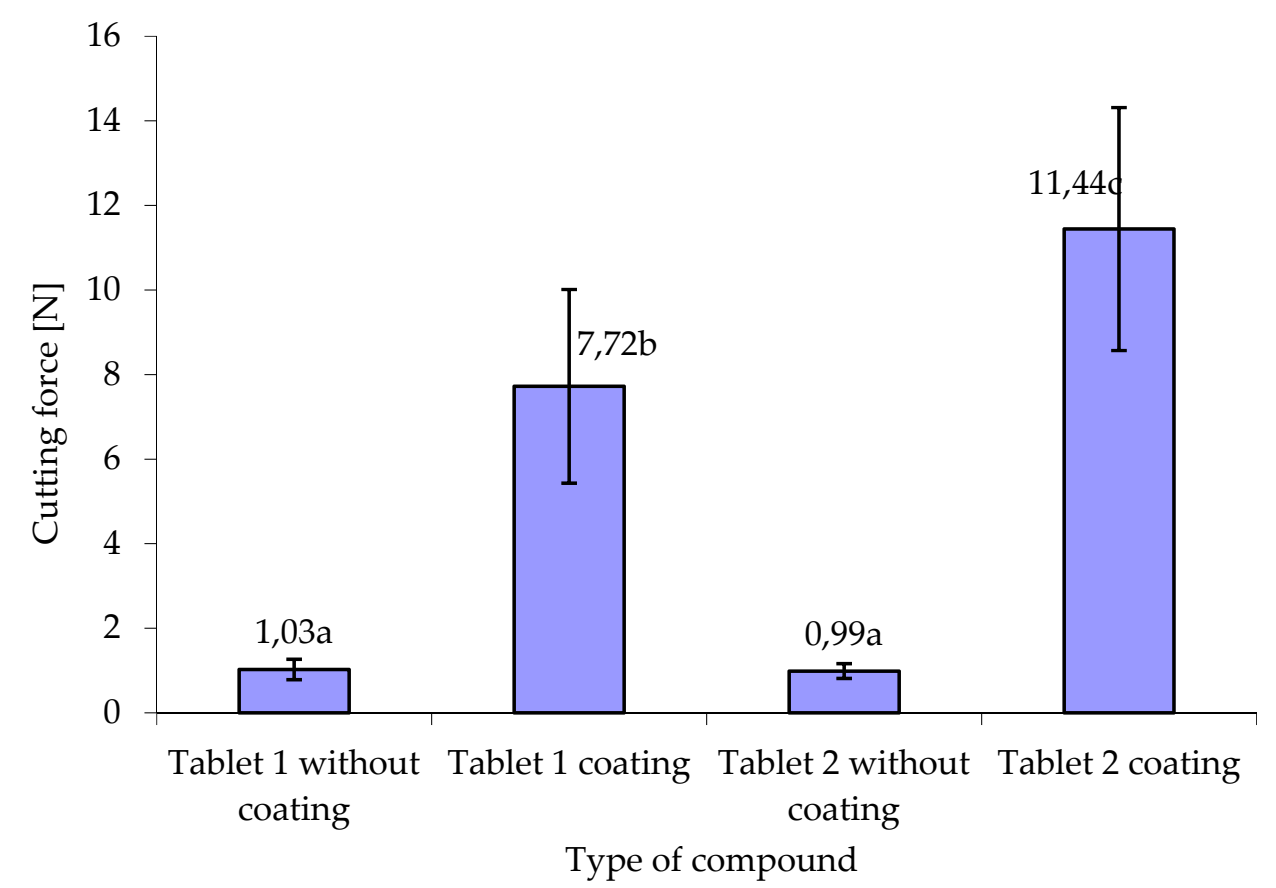

Figure 6. Maximum cutting force for individual tablets. 


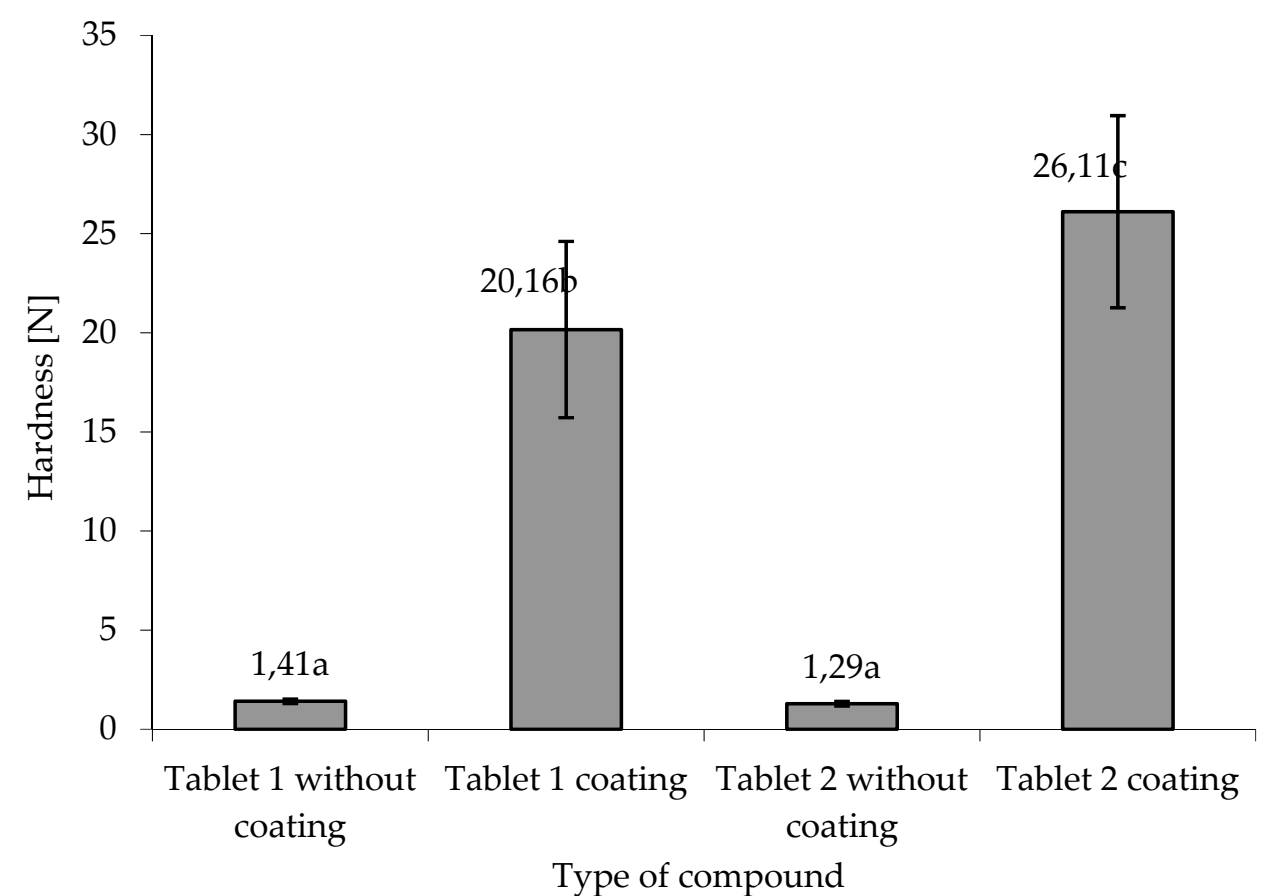

Figure 7. Hardness of the obtained tablets.

Table 4. Analysis of variance (ANOVA).

\begin{tabular}{cccccc}
\hline Source Variables & SS & df & MS & F Value & Probability \\
\hline Compaction work $[\mathrm{J} / \mathrm{g}]$ & 0.1652 & 1 & 0.1652 & 3.578845 & 0.063046 \\
${\text { Specific density }\left[\mathrm{g} \cdot \mathrm{dm}^{-3} \text { ] }\right.}_{\text {Cutting force }[\mathrm{N}]}^{659.469}$ & 1 & 659.469 & 1.038803 & 0.311938 \\
Hardness $[\mathrm{N}]$ & 570,115 & 3 & 190.038 & 61.1161 & 0 \\
& 3598.742 & 3 & 1199.581 & 117.406 & 0 \\
\hline
\end{tabular}

As confirmed by the study tablets with starch coating are characterized by greater resistance to cutting. The maximum cutting force was recorded for tablet 2, i.e. the one with honey powder admixture. Temperature increase caused by friction force resulting from compression transforms powdered honey into a viscous liquid which reinforces produced tablet. In order to obtain high quality agglomerate it is necessary to combine this raw material with other raw materials that provide appropriate strength properties $[37,38]$.

A similar relationship was obtained during the tablet hardness tests. The tablets with addition of honey powder and coated with starch were characterised by highest hardness $(26.11 \mathrm{~N})$. Statistical analysis of the results confirmed the significance of the differences between the tablets with honey powder admixture and those without it. This greater hardness of the tablets with honey results from its bonding with the other components constituting the compound, as well as with the applied starch coating. Tablets without coating were characterised by low hardness of 1.3-1.4 N, regardless of the admixture of honey powder. Studies on the impact of coating on the properties of final product were done for many sectors of the food industry. As demonstrated by the research done by Fijałkowska et al. [39] after applying a coating of thermally hardened starch on dried apple a slight increase in the hardness of dried apple was recorded as compared with the control sample [40]. Another advantage is extending the freshness of a variety of fruits by applying a coating and thus controlling the water content in the fruits, as well as their colour and firmness [41].

The presented diagram (Figure 8) illustrates the technologies of producing a new product that can be used in food preparations as dietary supplements. 


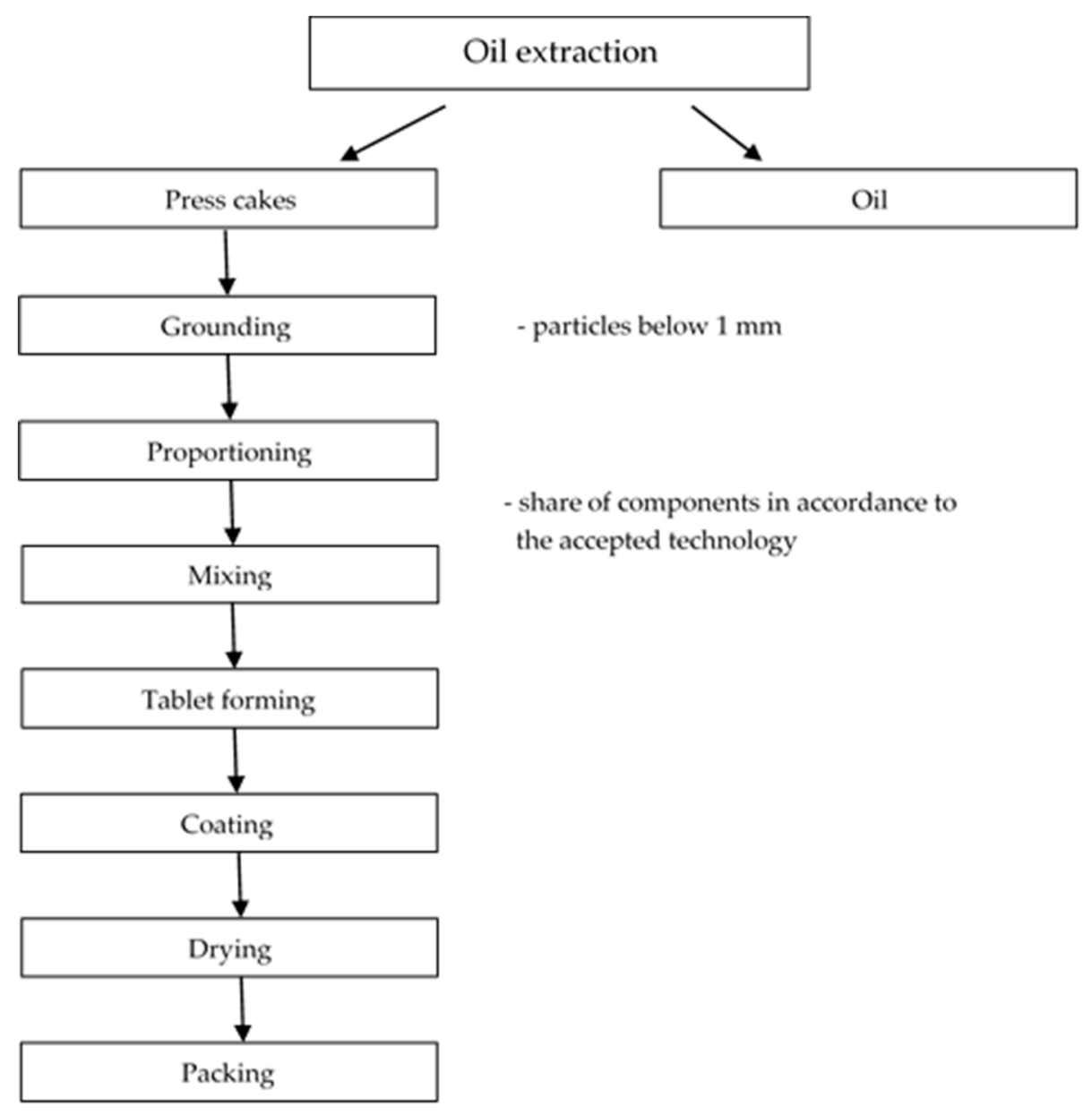

Figure 8. Prospects for using by-products of oil production.

\section{Conclusions}

The potential of some organic wastes is not always fully appreciated. They can be useful basic raw materials which can be sources of valuable, previously unknown or overlooked ingredients. The studies carried out suggest the possibility for using post-production press cakes in the manufacture of food products immediately after oil pressing (without the need of transport of post-production press cakes). The products obtained have a high protein content and significant amounts of minerals. An appropriate compaction process of the ingredients and application of a coating also allows for obtaining tablet of appropriate quality. Products with starch $(40 \%$ solution of potato starch) coating and enriched with $2 \%$ honey powder are characterized by greater resistance to cutting and better hardness.

The proposal for organic waste compaction process resulting from cold-press oil extraction presented here can significantly increase profitability of processing raw materials. Moreover, manufacture of new products having the characteristics of pro-health food will also enhance the food market and make it more attractive. Through the admixture of various flavor coatings (honey, chocolate, caramel) they could become a product for direct consumption.

Author Contributions: Conceptualization, P.S., K.Z., and D.A.; methodology, P.S., and D.A.; formal analysis, A.S. (Agnieszka Sagan), P.S.; investigation, P.S., A.S. (Agnieszka Starek), B.Z. and W.Ż.-S.; data curation, P.S., A.S. (Agnieszka Starek); writing—original draft preparation, A.S. (Agnieszka Starek), P.S.; writing—review and editing, A.S. (Agnieszka Starek), A.S. (Agnieszka Sagan); visualization, P.S., A.S. (Agnieszka Starek); supervision, P.S. All authors have read and agreed to the published version of the manuscript.

Funding: This research received no external funding. 
Acknowledgments: The samples of chemical analysis have been examined at the Regional Research Center for Environment, Agricultural and Innovative Technologies, Pope John II State School of Higher Education in Biała Podlaska.

Conflicts of Interest: The authors declare no conflict of interest.

\section{References}

1. Darlington, R.; Staikos, T.; Rahimifard, S. Analytical methods for waste minimization in the convenience food industry. Waste Manag. 2009, 4, 1274-1281. [CrossRef]

2. Garcia-Garcia, G.; Woolley, E.; Rahimifard, S. Identification and analysis of attributes for industrial food waste management modelling. Sustainability 2019, 11, 2445. [CrossRef]

3. Martin, M.; Danielsson, L. Environmental implications of dynamic policies on food consumption and waste handling in the European union. Sustainability 2016, 8, 282. [CrossRef]

4. Shin, S.G.; Han, G.; Lim, J.; Lee, C.; Hwang, S.A. Comprehensive microbial insight into two-stage anaerobic digestion of food waste-recycling wastewater. Water Res. 2010, 44, 4838-4849. [CrossRef] [PubMed]

5. Strotmann, C.; Göbel, C.; Friedrich, S.; Kreyenschmidt, J.; Ritter, G.; Teitscheid, P.A. Participatory approach to minimizing food waste in the food industry-A manual for managers. Sustainability 2017, 9, 66. [CrossRef]

6. Ahern, N.A.; Nuttelman, B.L.; Klopfenstein, T.J.; MacDonald, J.C.; Erickson, G.E.; Watson, A.K. Comparison of wet and dry distillers grains plus solubles to corn as an energy source in forage-based diets. Prof. Anim. Sci. 2016, 32, 758-767. [CrossRef]

7. Kaczmarek, P.; Korniewicz, D.; Lipiński, K.; Mazur, M. Chemical composition of rapeseed products and their use in pig nutrition. Pol. J. Nat. Sci. 2016, 4, 545-562.

8. Świerczewska, E.; Mroczek, J.; Niemiec, J.; Słowiński, M.; Jurczak, M.; Siennicka, A.; Kawka, P. Broiler chick performance and meat quality depending on the type of fat in feed mixtures. J. Anim. Feed Sci. 1997, 6, 379-389. [CrossRef]

9. Appels, L.; Lauwers, J.; Degrève, J.; Helsen, L.; Lievens, B.; Willems, K.; Dewil, R. Anaerobic digestion in global bio-energy production: Potential and research challenges. Renew. Sustain. Energy Rev. 2011, 15, 4295-4301. [CrossRef]

10. Maćkowiak, C.; Igras, J. Chemical composition of sewage sludge and food industry wastes of fertilisation value. Inż. Ekol. 2005, 10, 70-77.

11. Singh, R.P.; Ibrahim, M.H.; Esa, N.; Iliyana, M.S. Composting of waste from palm oil mill: A sustainable waste management practice. Rev. Environ. Sci. Biotechnol. 2010, 9, 331-344. [CrossRef]

12. Yaakob, Z.; Mohammad, M.; Alherbawi, M.; Alam, Z.; Sopian, K. Overview of the production of biodiesel from waste cooking oil. Renew. Sustain. Energy Rev. 2013, 18, 184-193. [CrossRef]

13. Kraszkiewicz, A.; Kachel-Jakubowska, M.; Niedziółka, I.; Zaklika, B.; Zawiślak, K.; Nadulski, R.; Mruk, R. Impact of various kinds of straw and other raw materials on physical characteristics of pellets. Annu. Set Environ. Prot. 2017, 19, 270-287.

14. Zawiślak, K.; Sobczak, P.; Kraszkiewicz, A.; Niedziółka, I.; Parafiniuk, S.; Kuna-Broniowska, I.; Tanaś, W.; Żukiewicz-Sobczak, W.; Obidziński, S. The use of lignocellulosic waste in the production of pellets for energy purposes. Renew. Energy 2020, 145, 997-1003. [CrossRef]

15. Wojdalski, J.; Grochowicz, J.; Ekielski, A.; Radecka, K.; Stępniak, S.; Orłowski, A.; Kosmala, G. Production and Properties of Apple Pomace Pellets and their Suitability for Energy Generation Purposes. Annu. Set Environ. Prot. 2016, 18, 89-111.

16. Ramachandran, S.; Roopesh, K.; Nampoothiri, K.M.; Szakacs, G.; Pandey, A. Mixed substrate fermentation for the production of phytase by Rhizopus spp. using oilcakes as substrates. Process Biochem. 2005, 40, 1749-1754. [CrossRef]

17. Ramachandran, S.; Singh, S.K.; Larroche, C.; Soccol, C.R.; Pandey, A. Oil cakes and their biotechnological applications-A review. Bioresour. Technol. 2007, 98, 2000-2009. [CrossRef]

18. Flores, M.; Saravia, C.; Vergara, C.E.; Avila, F.; Valdés, H.; Ortiz-Viedma, J. Avocado Oil: Characteristics, Properties, and Applications. Molecules 2019, 24, 2172. [CrossRef]

19. Soong, Y.Y.; Barlow, P.J. Antioxidant activity and phenolic content of selected fruit seeds. Food Chem. 2004, 88, 411-417. [CrossRef] 
20. Wang, W.; Bostic, T.R.; Gu, L. Antioxidant capacities, procyanidins and pigments in avocados of different strains and cultivars. Food Chem. 2010, 122, 1193-1198. [CrossRef]

21. Alex, S.; Nogent, L.; Caroline, B.; Sophie, L.B.; Philippe, M. Avocado Flesh and/or Skin Extract Rich in Polyphenols and Cosmetic, Dermatological and Nutraceutical Compositions Comprising Same. United States Patent Application No. 16/117, 511, 30 August 2018.

22. Segovia, F.; Hidalgo, G.; Villasante, J.; Ramis, X.; Almajano, M. Avocado seed: A comparative study of antioxidant content and capacity in protecting oil models from oxidation. Molecules 2018, 23, 2421. [CrossRef]

23. Alkhalf, M.I.; Alansari, W.S.; Ibrahim, E.A.; ELhalwagy, M.E. Anti-oxidant, anti-inflammatory and anti-cancer activities of avocado (Persea americana) fruit and seed extract. J. King Saud Univ. Sci. 2018, 31, 1358-1362. [CrossRef]

24. Dabas, D.; Elias, R.J.; Ziegler, G.R.; Lambert, J.D. In Vitro Antioxidant and Cancer Inhibitory Activity of a Colored Avocado Seed Extract. Int. J. Food Sci. 2019. [CrossRef]

25. Lara-Marquez, M.; Spagnuolo, P.A.; Salgado-Garciglia, R.; Ochoa-Zarzosa, A.; Lopez-Meza, J.E. Cytotoxic Mechanism of Long-chain Lipids Extracted from Mexican Native Avocado Seed (Persea americana var. drymifolia) on Colon Cancer Cells. FASEB J. 2018, 32, 804-832.

26. Vo, T.S.; Le, P.U. Free radical scavenging and anti-proliferative activities of avocado (Persea americana Mill.) seed extract. Asian Pac. J. Trop. Med. 2019, 9, 91.

27. Berbel, J.; Posadillo, A. Review and analysis of alternatives for the valorisation of agro-industrial olive oil by-products. Sustainability 2018, 10, 237. [CrossRef]

28. Zafeiriou, E.; Arabatzis, G.; Karanikola, P.; Tampakis, S.; Tsiantikoudis, S. Agricultural commodities and crude oil prices: An empirical investigation of their relationship. Sustainability 2018, 10, 1199. [CrossRef]

29. Biopaliwa Stałe-Oznaczanie Zawartości Popiołu; Polish Committee for Standardization: Warsaw, Poland, 2016; PN-EN ISO 18122:2016-01.

30. Biopaliwa Stałe-Oznaczanie Zawartości Wilgoci-Metoda Suszarkowa-Część 3: Wilgoć w Próbce do Analizy Ogólnej; Polish Committee for Standardization: Warsaw, Poland, 2015; PN-EN-ISO 18134-3:2015-11.

31. Popović, L.; Peričin, D.; Vaštag, Ž.; Popović, S.; Krimer, V.; Torbica, A. Antioxidative and functional properties of pumpkin oil cake globulin hydrolysates. J. Am. Oil Chem. Soc. 2013, 90, 1157-1165. [CrossRef]

32. Salgado, P.R.; Molina Ortiz, S.E.; Petruccelli, S.; Mauri, A.N. Sunflower protein concentrates and isolates prepared from oil cakes have high water solubility and antioxidant capacity. J. Am. Oil Chem. Soc. 2011, 88, 351-360. [CrossRef]

33. Mohdaly, A.A.; Smetanska, I.; Ramadan, M.F.; Sarhan, M.A.; Mahmoud, A. Antioxidant potential of sesame (Sesamum indicum) cake extract in stabilization of sunflower and soybean oils. Ind. Crop. Prod. 2011, 34, 952-959. [CrossRef]

34. Yasothai, R. Chemical composition of sesame oil cake-Review. Int. J. Sci. Environ. Technol. 2014, 3, 827-835.

35. Amarowicz, R.; Fornal, J.; Karamac, M. Effect of seed moisture on phenolic acids in rapeseed oil cake. Grasas Aceites 1995, 46, 354-356. [CrossRef]

36. Terpinc, P.; Čeh, B.; Ulrih, N.P.; Abramovič, H. Studies of the correlation between antioxidant properties and the total phenolic content of different oil cake extracts. Ind. Crop. Prod. 2012, 39, 210-217. [CrossRef]

37. Miranda, T.; Arranz, J.I.; Montero, I.; Román, S.; Rojas, C.V.; Nogales, S. Characterization and combustion of olive pomace and forest residue pellets. Fuel Process. Technol. 2012, 103, 91-96. [CrossRef]

38. Obidziński, S. Analysis of usability of potato pulp as solid fuel. Fuel Process. Technol. 2012, 1, 67-74. [CrossRef]

39. Fijałkowska, A.; Witrowa-Rajchert, D.; Weroński, A. The influence of raw material coating on drying process and reconstitution properties of dried product. Zesz. Probl. Postęp. Nauk Roln. 2012, 571, 39-47.

40. Krochta, J.M.; De Mulder-Johnston, C. Edible and biodegradable polymer films: Challenges and opportunities. Food Technol. 1997, 51, 61-74.

41. García, M.A.; Martino, M.N.; Zaritzky, N.E. Plasticized starch-based coatings to improve strawberry (Fragaria×ananassa) quality and stability. J. Agric. Food Chem. 1998, 46, 3758-3767. [CrossRef]

(C) 2020 by the authors. Licensee MDPI, Basel, Switzerland. This article is an open access article distributed under the terms and conditions of the Creative Commons Attribution (CC BY) license (http://creativecommons.org/licenses/by/4.0/). 